Original research article

\title{
Continuous care of cancer patients through the lens of social work
}

\author{
Lucia Tóthová *, Eva Žiaková, Katarína Šiňanská \\ Pavol Jozef Šafárik University in Košice, Faculty of Arts, Department of Social Work, Košice, Slovak Republic
}

\begin{abstract}
The paper explains the importance of the role of social workers in multidisciplinary teams providing continuous care for oncologic patients. Abroad, oncology social workers are members of these teams. The authors propose adopting this practice and involving social workers in oncology treatment in Slovakia since this approach is currently missing. An information guide (brochure) is proposed to raise awareness of the social preventive measures, social treatment, and social patient care, to explain and justify the social risk aspects and consequences of cancer, and to address it in terms of social work. In terms of the multidisciplinary approach, the paper empirically examines the attitudes of oncologists and oncology nurses towards such a brochure. The results indicate that the respondents have a positive attitude to the brochure and to social care for cancer patients.
\end{abstract}

Keywords: Attitude; Continuity; Multidisciplinarity; Oncology social work

\section{Introduction}

The changes in today's world are forcing us to think about many facts related to people's lifestyles, health, and social changes. We could rightly call these changes "storms or gales" that change everything about our lives and thus our health. Some consequences of the current global changes are not yet visible, but it is clear that the way we see our life, self-care, and our surroundings needs to be reviewed.

If we pay more attention to signals from nature, it is possible that we will understand and find the right direction for to live a healthy and happy life. This also applies to well-known diseases of civilisation such as cancer.

This paper was created with the intention of looking for a route to health - even for people who cannot see the route or find it. The paper was also created due to the need to successfully and productively involve professionals - social workers in the field of cancer treatment, following the successful and productive experiences of their colleagues worldwide.

\section{Inevitable multidisciplinarity}

Besides physical symptoms of the illness, oncologic patients often face difficulties such as performance decline, loss of mobility, need for psychosocial adaptation to a new situation in personal relationships, coping with stressful situations and everyday life. In this context, over the last few years, the necessity of a multidisciplinary approach to treatment and rehabilitation of oncologic patients has been emphasized.
Over the last 40 years, multidisciplinary teams have evolved at different rates in many areas. A multidisciplinary team (MDT) is a group of health care workers with different fields of expertise who cooperate in a more complicated environment such as a clinic, hospital ward, rehabilitation centre, assistance centre, etc. (Giles, 2016; Klein, 2005). A MDT's goal is to develop a common way to understand the problems (Wagner et al., 2011), the solution to which requires a combination of multiple disciplines or fields of research practice (Academy of Sciences, National Academy of Engineering and Institute of Medicine, 2005).

Many clients view having "their own" team providing multidisciplinary care as a privilege. Establishing such teams is considered an innovation in health and social care that offers integrated personalised care and support (NHS England, 2014). It follows the Person Centred Care trend that is currently developing (Fig. 1). The specific form of Person Centred Care depends on the needs, circumstances, and preferences of the patient. Some things can be important for one client and pointless or even undesirable for the other. Needs may also change over time (NHS England, 2014).

The specialisation of the team members depends on the individual client's needs; in each case, a unique care team is established and its members can also change to cater to the client's current clinical and psychosocial needs (Mitchell et al., 2008). If interdisciplinary cooperation is effective, high quality care is delivered to the clients (Giles, 2016).

The tasks assigned to individual team members are managed using a care plan, which covers the problematic areas

\footnotetext{
* Corresponding author: Lucia Tóthová, Pavol Jozef Šafárik University in Košice, Faculty of Arts, Department of Social Work, Moyzesova 9, 04059 Košice, Slovak Republic; e-mail: lucia.tothova1@upjs.sk http://doi.org/10.32725/kont.2020.037

Submitted: 2020-04-08 • Accepted: 2020-09-23 • Prepublished online: 2020-09-29 


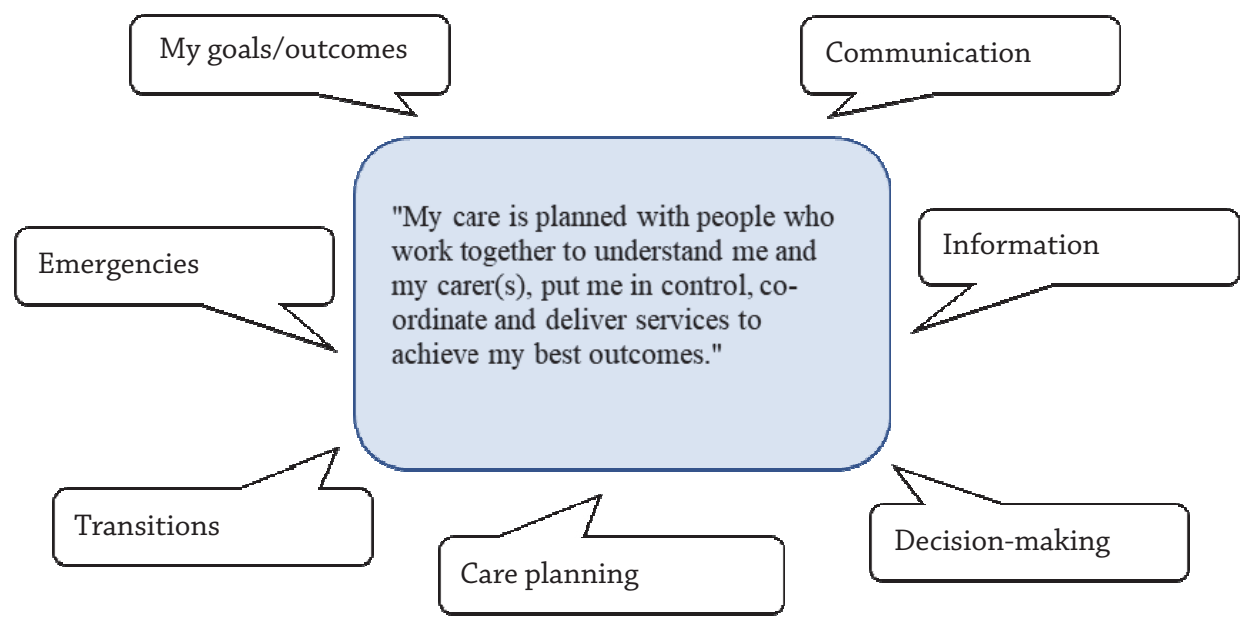

Source: NHS England (2014, p. 6)

Fig. 1. Person centred coordinated care

identified, establishes solution procedures, and determines specific goals. The care plan is agreed upon by the client and the team of medical workers, and it is written in a comprehensible way. If the client wishes so, their family members or close ones can be included in the plan. The plan is updated as needed, usually once a week, and the multidisciplinary team meets to review it. The care plan helps to coordinate individual shifts and the multidisciplinary team cooperates to achieve specific goals (Health Service Executive, 2020).

Usually, the client has a designated so-called 'key worker', also known as the care coordinator, who becomes the main point of contact for him or her. This expert develops a proactive professional relationship with the client. He is to represent a continuous point of contact for the client. He perceives clients holistically, defends them, helps them to navigate the health and social care systems, takes over planning the client's care, and also monitors and reviews care plans in cooperation with other experts and the client (NHS England, 2014).

Cooperation among multiple helping professionals in oncology is a common practice abroad - interdisciplinary cooperation is promoted to provide a holistic approach to the patient. Each professional has a role in the support system. Social workers in teams play an important role in clients' evaluation, treatment, and rehabilitation, therefore they must be trained for teamwork during their studies - it can significantly improve their position (Francis, 2015). They coordinate clients and their families, community organisations, and MDT members; create care plans; facilitate clients' releasing from health facilities; support efficient communication between doctors, clients, and their family members (focused on clarifying the situation and giving the patient an opportunity to express their worries); and last but not least, they act as the client's advocates (Giles, 2016).

MDTs offer a number of benefits for patients as well as their medical worker members. Specific forms of communication, learning from each other, coming to terms with one's professional identity as the tasks change and the responsibility shifts from one professional to another within the MDT, and other specificities arising from close cooperation among different experts often require a quick response that offers little time to adapt. However, social work has everything in place to accept the challenge and succeed. A social worker as a professional offering complex services, assistance, support, and company, represents a fully-fledged member of any inter-, multi-, or transdisciplinary team that provides clients with holistic care. MDT professionals confirm that in teams with clearly specified rules, professional identity can be maintained while gaining valuable knowledge about how other experts approach the same problem. They feel committed to teamwork, which provides a foundation for developing effective common procedures (Frost et al., 2005).

\section{Continuous care in oncology social work}

Oncology social work has developed as a specialisation of medical social work. Its beginnings can be traced back to the early 1960s in the USA. Today, oncology social work in the USA is a fully-fledged profession - with a national organisation providing education and support to oncology social workers in performing psychosocial intervention and research aimed at improving the methods to serve clients battling oncologic illness and their families (Fobair et al., 2009).

The Association of Oncology Social Work (AOSW, 2020) defines oncology social work as a profession designed to help the patients make the best use of the health care system, develop optimal coping strategies, and mobilise community resources to ensure maximum effectiveness. Oncology social workers provide service to the clients and their families, and work in multidisciplinary teams. Their key role is to evaluate the needs of the patient and their family and intervene to help solve the client's physical, psychological, interpersonal, and environmental problems. Their unique knowledge of the patient's needs and resources as well as their relationship with the patient and their family contributes to successful treatment. Oncology social workers work across different fields to provide care and help improve oncologic patients' health and well-being (Zebrack et al., 2012).

According to the National Association of Social Workers (NASW, 2020), oncology social workers provide a variety of services. They provide assistance to clients and their close ones from the point when the patient is diagnosed, during the time they are battling the chronic illness, and if it proves fatal, they also accompany the patient during the final stage of their life. The social worker's role is an integral and fundamental part of all oncologic care. Patients perceive oncology social work- 
ers' service as an irreplaceable bridge to spiritual, mental, and social support on their way to regain health. Using the social workers' service is voluntary, however oncologic patients do so frequently, based on the recommendation from their doctors, nurses, friends, and other patients. Sometimes, patients address social workers due to practical reasons - they need help to pay rent, organise transport, discuss the ways of continuing to work, or how to talk about the diagnosis to their children or other family members and friends.

Oncologic patients not only need multidisciplinary, but also continuous care, since the nature of their illness is chronic. Cancer "never sleeps" and it can progress despite the invisibility of its symptoms. Continuity requires all professionals involved to "check" each step in prevention, treatment, and the return to normal life afterwards. Therefore, the following applies (Zebrack et al., 2015):
- oncology social work takes the form of continuous care from diagnostics through all stages of treatments to a successful return to health or a terminal stage that cannot be cured;

- patient oriented care can be seen as theoretical conceptualisation of their complex experience involving a variety of psychosocial, spiritual, and cultural questions;

- providing quality care for oncologic patients in the 21st century requires oncology social workers to provide services tailored to the stage in which the patient and their family currently are in terms of continuous care.

Zebrack et al. (2015) proposed the following model of continuous care (Fig. 2). If we follow it, we can maximize the patient's chances of survival.

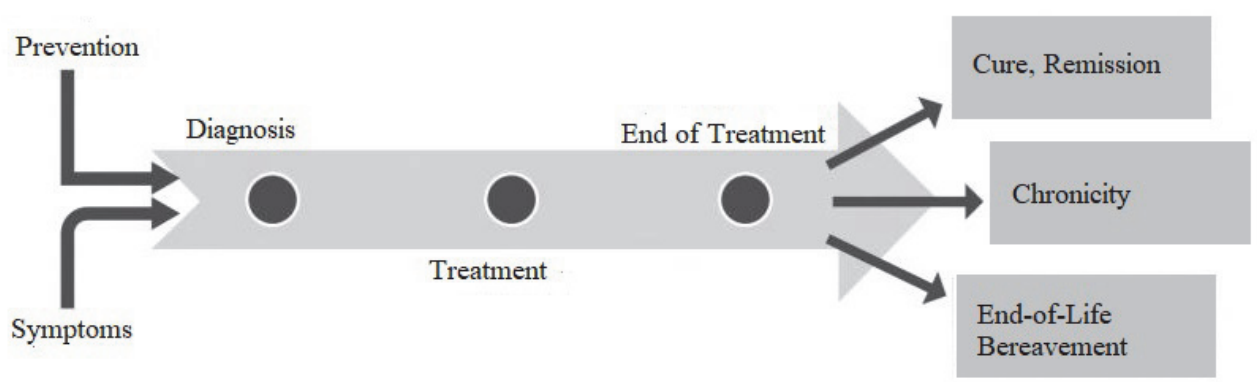

Source: Zebrack et al. (2015, p. 36)

Fig. 2. Continuous care for oncologic patients

Based on this model, the oncology social worker should approach all stages of continuous care holistically. The common factor is the patient oriented approach, which aims to work with the patient and their family in all areas of care to help them return to their natural personal and social roles.

Zebrack et al. (2015) indicate that to properly cope with the treatment (in all stages - after a surgery, chemotherapy, radiotherapy, or biological therapy) requires the patient to fully understand medical information, handle the side effects, cope with everyday stress, manage emotional responses (their own and other people's), continue social and physical activity if possible, seek the support of one's significant other, and accept the illness and its stages.

\section{Materials and methods}

The authors aimed to raise the level of awareness of oncologic illness as multifactorial and multicausal illness and the role of social work in managing them through a multidisciplinary approach to treatment and rehabilitation of oncologic patients receiving continuous care. In terms of a KEGA research project, the authors are developing a guide (brochure) for oncologic patients as well as the public. The guide will provide information on the illness through the lens of social work, address prevention as well as coping with cancer in terms of social and psychological risk factors.

To ensure multidisciplinary cooperation, that is important in the issue of cancer, research was performed to identify oncologists' and oncology nurses' attitude to the content and purpose of the patient handbook, as well as to the role of the social worker in the multidisciplinary team. At first, the authors intended to focus specifically on oncologists, but due to their unwillingness to participate in the research, oncology nurses were added as respondents.

The goal of the research was to identify experts' attitudes to social and psychological care for cancer patients and cancer prevention through the lens of social work, and take the findings into account in designing the guide. An attitude can be interpreted from manifestations and responses of an individual or a group of people and it can take the form of words, actions, or thoughts; it has cognitive (knowledge of objects), emotional (emotional evaluation), and conative aspects (the tendency to act) (Kollárik, 2004).

Although attitudes are traditionally measured using qualitative methods, the authors opted for quantitative research, which allows for measuring multiple variables, description of variable behaviour, and testing of hypotheses using as many respondents as possible. A questionnaire designed by the authors was used to collect data on doctors' and nurses' attitudes in the three aforementioned attitudinal aspects. The items were selected in a way that prevented influencing the respondents, i.e. they were formulated as positive as well as negative statements.

The respondents answered 23 questions using a 5-point Likert scale allowing the researchers to calculate the overall score. The lower the score, the stronger the proponent of the respective attitude. Minimum and maximum scores were 23 and 115 points respectively. The following applied to the individual attitudinal components: cognitive component: 7-35 points (7 questions); emotional component: 10-50 points (10 questions); conative component: $6-30$ points (6 questions). The lower the score, the more the respondent identified with the respective statement; the higher the score, the less the respondent identified with the statement. 
The questionnaire consisted of two other parts. In the first part, respondents answered open questions regarding the information necessary for oncologic patients from the social and psychological points of view, while the second part focused on sociodemographic data about the respondents.

Reliability of the questionnaire was verified using Cronbach's alpha coefficient and the instrument achieved good internal consistency at $\alpha=0.862$. It was also approved by the ethical committee of the Východoslovenský onkologický ústav in Košice, and questionnaires were administered personally during the XXIII Košice Chemotherapy Days. $81(N=81)$ respondents participated in the survey; all of them were oncologists or oncology nurses working in Košice, Prešov, Bratislava, Rimavská Sobota, Spišská Nová Ves, and Bardejov; their average age was 41 and their average length of medical practice was 17 years. Females were predominant $(N=63)$.

\section{Results}

In this part of the paper, the authors will present the selected research results on the oncologists' and oncology nurses' attitudes to social and psychological care for oncologic patients and cancer prevention through the lens of social work using a guide accessible to every patient.

Almost all respondents in the research sample stated that oncologic patients need a psychologist and social worker as well as the physician during their treatment (Chart 1 ). This results from their perception of health as a state of complete physical, mental and social well-being. The findings also relate to the respondents' knowledge about the origin and course of oncologic illness, which integrate biological, genetic, mental, social, environmental, and other factors, and the importance of prevention that takes the social factors into consideration.

Beside the doctor, a psychologist and social worker are also important in an oncologic patient's treatment

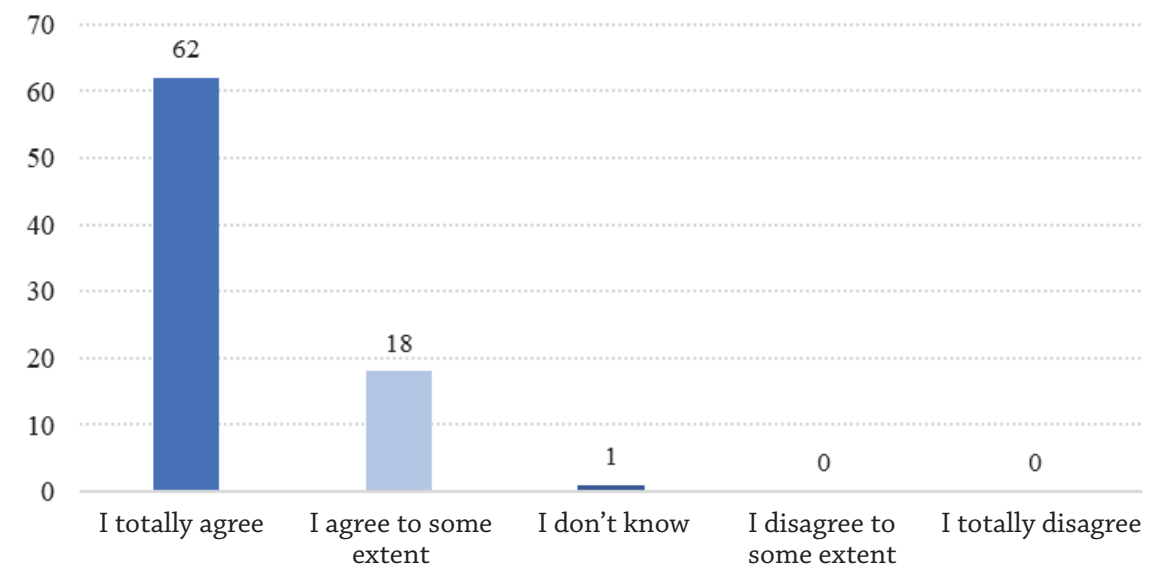

Chart 1. Frequency of answers to respective questions

Abroad, an (oncology) social worker plays the key role in care for an oncologic patient

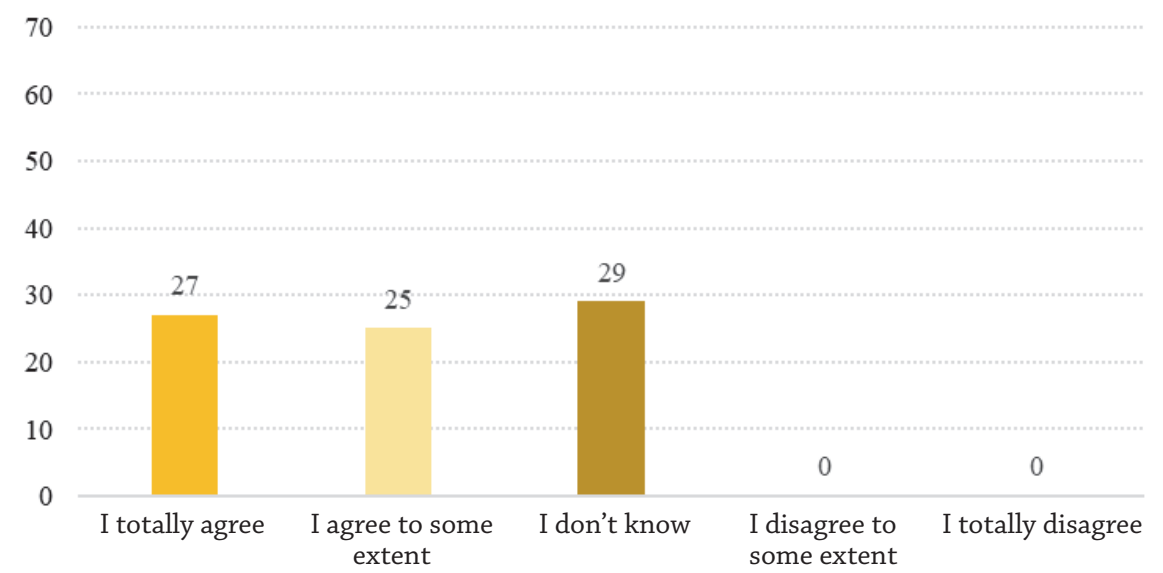

Chart 2. Frequency of answers to respective questions

Surprisingly, more than $35 \%$ of respondents were not aware that (oncology) social workers played a key role in care for oncologic patients abroad (Chart 2).
An important and authoritative finding for the research team was that the respondents do not consider the role of social work in solving the problem of oncological disease to be 
unnecessary, with the exception of 17 respondents. The results indicate that oncology social work is perceived positively, since almost $83 \%$ of respondents would like to see oncology social work introduced in Slovakia and $84 \%$ of them would hire a social worker for the team that cares for oncologic patients. However, in $45.6 \%$ of them, the inclusion of social workers in oncology departments in Slovakia raises the question of their sufficient qualifications and competencies. Nevertheless, sixty-three respondents feel the need to involve other areas in solving the problem of oncological disease, e.g. social work, mainly due to the increasing incidence as well as more patients with longer survival times. This is also confirmed by more than $90 \%$ of respondents who would direct the patient to a social worker in social questions.

$72.8 \%$ of the respondents believe that social work has a role in cancer prevention and more than two thirds (59) of them would recommend the patient to consult a guide about the social aspects of oncologic illness and cancer prevention. Chart 3 shows that respondents responded positively to the idea of a brochure.

If a brochure was available addressing oncologic illness in terms of social and psychological risk factors. I would recommend it to patients.

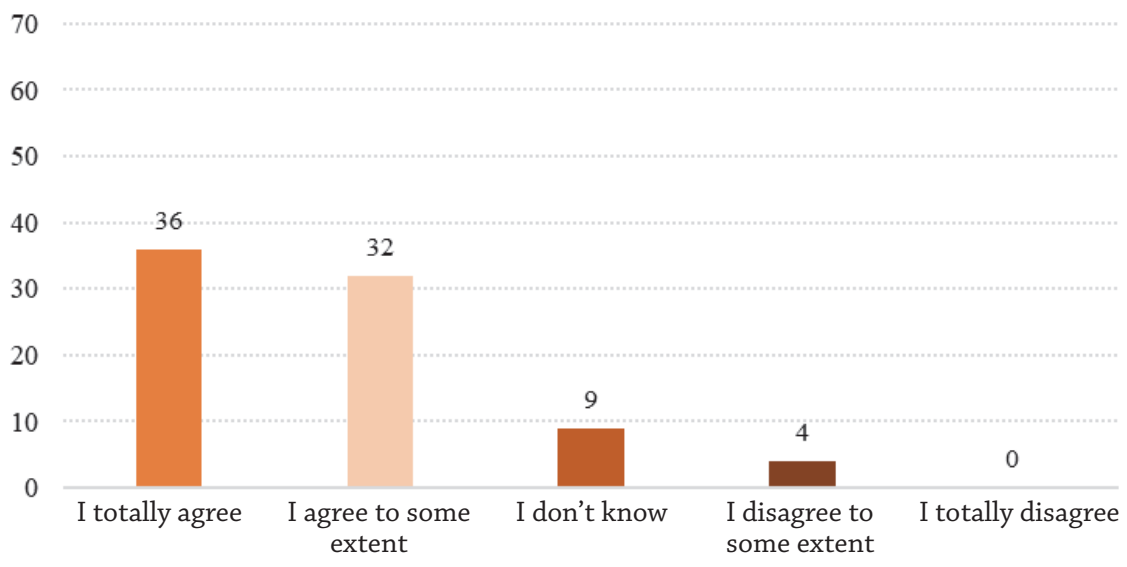

Chart 3. Frequency of answers to respective questions

Based on the results presented in Table 1 , it can be stated that respondents showed a positive attitude to social and psychological care for oncologic patients and cancer prevention through the lens of social work. On the scale where $1=$ strongly agree (positive aspect) to 5 = strongly disagree (negative aspect), the respondents answered "strongly agree" most frequently in cognitive and conative components, and "mostly agree" in the emotional component.

\section{Table 1. The average score and mode of answers in} individual attitudinal components

\begin{tabular}{lccc} 
& $N$ & Mean & $\begin{array}{c}\text { Mode of } \\
\text { answer }\end{array}$ \\
\hline Cognitive attitudinal component & & 10.9259 & 1 \\
Emotional attitudinal component & 81 & 19.5432 & 2 \\
Conative attitudinal component & & 11.0988 & 1 \\
Attitude & & $\mathbf{4 1 . 5 6 7 9}$ & $\mathbf{1}$ \\
\hline
\end{tabular}

The fact reflects too in the average score in the individual attitudinal components and overall score as well; the attitude did not correlate with gender, age, length of practice, place of work, or respondents' profession. However, the approach to medicine, illness, and health seems to be relevant among oncologists and oncology nurses (Table 2).

Respondents preferring a purely biomedical approach to oncologic illness and those who prefer the biopsychosocial approach showed statistically significant differences in perceiving health and oncologic illness. The respondents preferring the biopsychosocial approach understand health as an overall condition of a human being including their physical, mental, and social well-being. They see the origin and course of an oncologic illness as an interaction of biological, genetic, mental, social, environmental, and other factors. On the contrary, respondents preferring a purely biomedical approach ignored the role of social and psychological factors. This explains the statistically significant difference between their perception of social work and its role in oncologic care. Respondents preferring the biopsychosocial approach tended to consider social work necessary - apart from their counterparts preferring the purely biomedical approach. The first group also noticed the role of social work in cancer prevention more frequently.

Other items in Table 2 did not show significant differences between the two groups of respondents when compared, however, the scores indicate that respondents preferring biopsychosocial approach would be more inclined to offer the patients the brochure on cancer prevention through the lens of social and psychological risk factors if it was available. They would also be more inclined to hire a social worker for the team caring for oncologic patients and welcome the introduction of oncology social work.

In the final part of the questionnaire, respondents had an opportunity to add information they would include in the brochure for oncologic patients regarding social and psychological aspects of their illness. The most frequent ideas included:

- contacts for support and self-help groups, and other organisations;

- information about and contact for ADOS (home nursing care agency);

- financial compensation;

- field social work possibilities;

- the importance of prevention; 
Table 2. The measured distinctions between the two respondent groups based on their approach to medicine

\begin{tabular}{|c|c|c|c|c|c|}
\hline & & $N$ & $X$ & $t$ & $p(\alpha)$ \\
\hline Biomedical approach & \multirow{2}{*}{ integrating factors } & 58 & 33.85 & \multirow{2}{*}{-2.995} & \multirow{2}{*}{$\mathbf{0 . 0 0 3}^{* *}$} \\
\hline Biopsychosocial approach & & 15 & 49.17 & & \\
\hline Biomedical approach & \multirow{2}{*}{ health as an overall condition } & 58 & 34.98 & \multirow{2}{*}{-2.802} & \multirow{2}{*}{$0.005^{* *}$} \\
\hline Biopsychosocial approach & & 15 & 44.80 & & \\
\hline Biomedical approach & \multirow{2}{*}{$\begin{array}{l}\text { need for social work in } \\
\text { tackling oncologic illness }\end{array}$} & 58 & 33.06 & \multirow{2}{*}{-3.351} & \multirow{2}{*}{$\mathbf{0 . 0 0 1 * *}$} \\
\hline Biopsychosocial approach & & 15 & 52.23 & & \\
\hline Biomedical approach & \multirow{2}{*}{$\begin{array}{l}\text { engaging social work in cancer } \\
\text { prevention }\end{array}$} & 58 & 34.57 & \multirow{2}{*}{-2.016} & \multirow{2}{*}{$0.044^{*}$} \\
\hline Biopsychosocial approach & & 15 & 46.40 & & \\
\hline Biomedical approach & \multirow{2}{*}{ offered brochure } & 58 & 35.19 & \multirow{2}{*}{-1.558} & \multirow{2}{*}{0.119} \\
\hline Biopsychosocial approach & & 15 & 44.00 & & \\
\hline Biomedical approach & \multirow{2}{*}{$\begin{array}{l}\text { social worker in the patient } \\
\text { care team }\end{array}$} & 58 & 35.47 & \multirow{2}{*}{-1.329} & \multirow{2}{*}{0.184} \\
\hline Biopsychosocial approach & & 15 & 42.90 & & \\
\hline Biomedical approach & \multirow{2}{*}{$\begin{array}{l}\text { introducing oncology social } \\
\text { work }\end{array}$} & 58 & 36.07 & \multirow{2}{*}{-0.802} & \multirow{2}{*}{0.422} \\
\hline Biopsychosocial approach & & 15 & 40.80 & & \\
\hline
\end{tabular}

- emphasizing the social and psychological aspects of the illness and its treatment, etc.;

- describe life with cancer and related social and psychological complications and limitations;

- self-care;

- socialising;

- including the family and friends.

\section{Discussion}

In this part of the paper, the research findings will be compared with other available research results; the overlap is partial due to the specificity of the research presented in this paper.

Obviously, oncologic illness represents one of the most significant issues of the 21st century. Abroad, experts in a variety of fields are tackling the situation, including social workers. One of the tools to address the issue can be information brochures or guides.

Vadaparampil et al. (2011) created a brochure addressing the lack of awareness regarding hereditary breast and ovary carcinoma and the increasing incidence of early breast carcinoma among black women. The awareness-raising brochure was designed with the cultural specificities in mind. Three focus groups were created to verify the relevance, clarity, and cultural appropriateness of the brochure. Based on feedback and data analysis, the researchers revised the brochure.

Freeman et al. (2010) focused on African Americans who are dying of colon and rectal cancer more frequently than any other racial or ethnic group; this group also seeks screening less often than other groups. The goal was to improve the educational brochures and promote screening. The respondents assessed six brochures focused on screening promotion. All of them felt that the final version of the brochure motivated them to discuss cancer screening with their health care provider. Simultaneously, the respondents helped identify the main obstacles in getting screened: cost, distrust towards doctors, and fear, which allowed the authors to address these worries.

The available educational materials on sexuality and intimacy for female breast cancer survivors designed specifically for white women inspired Yi et al. (2009) to develop and test the effectiveness of a culturally and style-specific brochure aimed at improving Asian female breast cancer survivors' quality of life, since sex is a taboo in many Asian communities. The brochure addressed the unique issues with intimacy and sexuality related to breast cancer and its diagnostics.

The authors of this paper had a similar goal - to identify what was missing in the complex approach to oncologic illness. In the Slovak environment, the social context of cancer is often overlooked, as well as the role of social work in oncologic illness treatment. Apart from the aforementioned research projects, the authors of this paper focused on oncologists and oncology nurses instead of patients to identify their opinion on cancer prevention in terms of social and psychological risk factors, thus approaching the matter in a multidisciplinary way. Oncology social work does not exist in Slovakia, and cancer is not perceived as an illness resulting from a combination of different factors including the social ones (unemployment, divorce, substance and non-substance addiction, poverty, loneliness, etc.).

The ultimate goal of the authors is to raise awareness among patients by means of a well-designed guide. Their first step was to identify what oncologists and oncology nurses thought about the proposed brochure and its contents. Despite the lack of practice in oncology social work, Slovak respondents expressed a positive attitude to the proposal of a brochure and the concept of social care for oncologic patients. Senf et al. (2019) studied doctors' attitudes to psycho-oncology. 102 doctors participated in the survey. The study showed that doctors trusted the effectiveness of psycho-oncology. The doctors in the study estimated their psychosocial education as average, but considered their psychosocial skills better than average.

The research presented in this paper showed that the respondents' attitude to oncology social work and the brochure in question was not influenced by their gender, age, length of practice, place of work, or profession - on the contrary, the only significant factor was their approach to medicine, illness, and health. However, specialised literature from different countries presents disparate results. For example, in an older 
research performed by Gross and Gross (1987), doctors were more inclined to accept social work than nurses. Mizrahi and Abramson (2000) analysed the attitudes of social workers and doctors toward common cooperation. One hundred respondents were categorised based on their approach to health and illness. Doctors with traditional opinions did not understand psychosocial problems adequately and saw social workers as providers of specific services and communication. Therefore their willingness to cooperate was limited to the necessary minimum; they emphasized the need for medical control of patient care. Doctors labelled as "transitive" appreciated other experts' contribution to patient care, but still saw themselves as team managers delegating certain aspects of patient care to social workers. They preferred target-oriented communication related to medical priorities. On the other hand, transformative doctors understood the broader concept of social work. They saw psychosocial aspects of care as the key factor for medical effectiveness. In this case, doctors and social workers worked in the same team and sought ways to communicate. Their work was mutually dependent and the responsibility for decision-making regarding patient care was shared; when describing their activities, they frequently referred to the team as "us", apart from their counterparts.

Parast and Allaii (2014) state that the professional relationship between social workers and doctors used to be somewhat tense in the past. Social workers considered the traditional model in which the doctor is emphasized as the highest authority to be a source of issues with health care in our society. However, the doctors' motivation to cooperate with social workers increased when they acknowledged that psychosocial intervention could improve medical results and increase the quality of life in older and chronically ill patients (Cook et al., 1996).

In terms of cooperation between doctors and social workers, doctors recommend the patient to social workers to consult social questions. More than $90 \%$ of respondents would recommend the patient to consult a social worker regarding social questions. Lilliehorn et al. (2019) performed a study in which social workers claimed that new contacts with patients were established based on a recommendation from a nurse $(41 \%)$ or doctor $(31 \%)$.

The goal of this paper was to point out the important role of social workers in multidisciplinary teams providing continuous care for oncologic patients. In terms of the multidisciplinary approach, the paper empirically studied the attitudes of oncologists and oncology nurses to social care for oncologic patients and the proposed brochure addressing cancer from the viewpoint of social work. The results indicate that respondents had a positive attitude to oncology social work as well as the proposed brochure. Integrated care for oncologic patients in which the doctors acknowledge the importance of holistic patient care during and after oncologic treatment has become a standard in many countries abroad.

\section{Conclusions}

The future of medical social work depends on the attitudes of doctors and nurses. The authors therefore focused on identifying their attitude on the role of social workers in multidisciplinary teams, as well as the purpose and contents of the proposed guide for patients as one way of caring for oncologic patients. It should draw attention to the importance of preventive measures from a social point of view, social treatment and patient care, explain the justification and significance of social risk aspects and consequences of oncological disease, and thus view oncological disease from the perspective of social work.

It can be stated that both doctors and nurses agree that successful treatment of oncologic patients is getting more difficult and multidimensional. The patient, as a lay person, is struggling to come to terms with their condition, navigate the information, and manage their own feelings and experiences. Tools summarising all the important information on what to do and how to manage their emotions are almost unavailable.

The findings indicate a trend that needs to be further discussed, highlighted and developed. In today's turbulent and ever-changing world, which paradoxically forces us to stop and think, we realize that any change, however unpredictable, reminds us that we need to change something in our approach to health, as it is not as it should be. The incidence of oncologic illness around the globe indicates that every person is or will be affected by cancer at some point, whether directly or indirectly. It is a major issue and needs to be taken into consideration.

\section{Conflict of interests}

The authors have no conflict of interests to declare.

\section{Acknowledgements}

The paper was created under the terms of the KEGA 008UPJŠ4/2019 "Prevencia onkologických chorôb optikou sociálnej práce"/"Prevention of oncological diseases through the optics of social work" research project.

\title{
Kontinuálna starostlivost' o onkologických pacientov optikou sociálnej práce
}

\begin{abstract}
Súhrn
Ciel'om príspevku je poukázat' na miesto a dôležitost' sociálneho pracovníka v multidisciplinárnom tíme v rámci kontinuálnej starostlivosti o pacientov s onkologickou diagnózou. Po vzore zahraničia, kde je (onkologický) sociálny pracovník súčastou takéhoto tímu, je snahou autoriek zapojit' sociálnych pracovníkov do oblasti onkologickej liečby aj v slovenských podmienkach, kde ich prítomnost' v tomto procese absentuje. Ako jednu z foriem starostlivosti zo strany sociálnej práce vnímajú autorky informačnú príručku (brožúru), ktorá by upozorňovala na dôležitost' preventívnych opatrení zo sociálneho hl'adiska, sociálnej liečby a starostlivosti o pacienta, vysvetl'ovala opodstatnenost' a význam sociálnych rizikových aspektov a dôsledkov onkologickej choroby, súhrnne, na onkologickú chorobu by nazerala optikou sociálnej práce. V zmysle zachovania multidisciplinarity skúma príspevok v empirickej rovine postoje lekárov a zdravotných sestier pôsobiacich v rámci onkologickej praxe k takejto brožúre. Výsledky poukazujú na to, že zapojení respondenti majú pozitívny postoj jednak k brožúre, ako aj k sociálnej starostlivosti o onkologických pacientov.
\end{abstract}

Kl'účové slová: kontinualita; multidisciplinarita; onkologická sociálna práca; postoj 


\section{References}

1. Academy of Sciences, National Academy of Engineering, Institute of Medicine (2005). Facilitating Interdisciplinary Research. Washington, DC: The National Academies Press, 332 p. DOI: 10.17226/11153.

2. AOSW (2020). What do oncology social workers do? [online] [cit. 2020-03-13]. Available from: https://www.aosw.org/

3. Cook CAL, Freedman JA, Freedman LD, Arick RK, Miller ME (1996). Screening for social and environmental problems in a VA primary care setting. Health Soc Work 21(1): 41-47. DOI: 10.1093/hsw/21.1.41.

4. Fobair P, Stearns NN, Christ G, Dozier-Hall D, Newman NW, Zabora J, et al. (2009). Historical threads in the development of oncology social work. J Psychos Oncol 27(2): 155-215. DOI: 10.1080/07347330902775301.

5. Francis A (2015). Social worker as a multidisciplinary team member: embedding 3 C'S (competence, confidence and compassion) in social work education in mental health. In: SWSD 2015: Joint World Conference on Social Work, Education and Social Development: programme and abstracts.

6. Freeman KL, Jandorf L, Thompson H, DuHamel, KN (2010). Colorectal cancer brochure development for African Americans. J Health Dispar Res Pract 3(3): 43-56.

7. Frost N, Robinson M, Anning A (2005). Social workers in multidisciplinary teams: issues and dilemmas. Child \& Family Social Work 10(3): 187-196. DOI: 10.1111/j.13652206.2005.00370.x

8. Giles R (2016). Social workers' perceptions of multi-disciplinary team work: a case study of health social workers at a major regional hospital in New Zealand. Aotearoa New Zealand Social Work 28(1): 25-33. DOI: 10.11157/anzswj-vol28iss1id113.

9. Gross AM, Gross J (1987). Attitudes of physicians and nurses towards the role of social workers in primary health care: What promotes collaboration? Family Practice 4(4): 266-270. DOI: 10.1093/fampra/4.4.266.

10. Health Service Executive (2020). What is a care plan? [online] [cit. 2020-06-25]. Available from: https://www.hse.ie/eng/ services/list/4/mental-health-services/dsc/dubwestsouth/help/ careplan.htmll

11. Klein JT (2005). Interdisciplinary teamwork: The dynamics of collaboration and integration. In: Derry SJ, Gernsbacher MA, Schunn CD (Eds). Interdisciplinary collaboration: An emerging cognitive science. New Jersey: Lawrence Erlbaum, pp. 23-50.

12. Kollárik T (2004). Sociálna psychológia. Bratislava: Univerzita Komenského, $545 \mathrm{p}$.

13. Lilliehorn S, Isaksson J, Salander P (2019). What does an oncology social worker deal with in patient consultations? -
An empirical study. Soc Work Health Care 58(5): 494-508. DOI: 10.1080/00981389.2019.1587661.

14. Mitchell GK, Tieman JJ, Shelby-James TM (2008). Multidisciplinary care planning and teamwork in primary care. Med J Aust 188(S8): S61-64.

15. Mizrahi T, Abramson JS (2000). Collaboration between social workers and physicians. Soc Work Health Care 31(3): 1-24. DOI: 10.1300/J010v31n03_01.

16. NASW (2020). Oncology social work. [online] [cit. 2020-0303]. Available from: http://www.socialworkers.org/pubs/ news/2015/04/oncology-social-work.aspNational

17. NHS England (2014). MDT development. Working toward an effective multidisciplinary/multiagency team. [online] [cit. 2020-02-24]. Available from: https://www.england.nhs.uk/wpcontent/uploads/2015/01/mdt-dev-guid-flat-fin.pdf

18. Parast SM, Allaii B (2014). The role of social work in health care system. Journal of Social Science for Policy Implications 2(2): $59-68$.

19. Senf B, Fettel J, Demmerle CH, Maiwurm P (2019). Physicians' attitudes towards psycho-oncology, perceived barriers, and psychosocial competencies: Indicators of successful implementation of adjunctive psycho-oncological care? Psychooncology 28(2): 415-422. DOI: 10.1002/pon.4962.

20. Vadaparampil ST, Quinn GP, Gjyshi A, Pal T (2011). Development of a brochure for increasing awareness of inherited breast cancer in black women. Genet Test Mol Biomarkers 15(1-2): 59-67. DOI: 10.1089/ gtmb.2010.0102.

21. Wagner CS, Roessner JD, Bobb K, Klein JT, Boyack KW, Keyton J, et al. (2011). Approaches to understanding and measuring interdisciplinary scientific research (IDR): A review of the literature. Journal of Informetrics 5(1): 14-26. DOI: 10.1016/j.joi.2010.06.004.

22. Yi JK, Daniel AM, Marley D (2009). Development and pilot testing of a brochure to improve quality of life among less acculturated Asian American breast cancer survivors. 137st APHA Annual Meeting and Exposition 2009. [online] [cit. 2020-02-05]. Available from: https://www.researchgate.net/ publication/266783155_Development_and_pilot_testing of_a_brochure_to_improve_quality_of_life_among_less_ acculturated_Asian_American_breast_cancer_survivors

23. Zebrack B, Burg MA, Vaitones V (2012). Distress screening: an opportunity for enhancing quality cancer care and promoting the oncology social work profession. J Psychosoc Oncol 30(6): 615-624. DOI: 10.1080/07347332.2012.721485.

24. Zebrack B, Jones BL, Smolinski KM (2015). Cancer across a continuum of care: clinical practice, opportunities, and challanges. In: Christ G, Messner C, Behar L (Eds). Handbook of oncology social work. New York: Oxford University Press, pp. 35-65. 